УДК 316.4.051.62

Піменова О.О., к. соц. н, доцент

Pimenova O. PhD in Sociology, Associate Professor https://orcid.org/0000-0003-3384-6806

Полухтович Т.Г., к. пед. н, доцент

Polukhtovych T.PhD in Pedagogical, Associate Professor https://orcid.org/0000-0002-0558-2981

\title{
ОСВІТА ДЛЯ АКТИВНОГО СТАРІННЯ ЯК ВИКЛИК СУЧАСНОСТІ
}

\section{Луцьький національний технічний університет}

\begin{abstract}
Старіння населення сьогодні набуває глобального характеру. За таких умов важливим стає пошук чинників, що є визначальними для конструктивних змін у цьому складному соціально-демографічному процесі.

Метою статті є - аналіз особливостей освітньої діяльності людей похилого віку у контексті активного старіння.

Освіта людей похилого віку розглядається як можливість індивідуально-особистісного та професійного розвитку. Визначено, що навчання протягом життя поглиблює розуміння навколишнього світу, а також надає більше можливостей для покращення якості життя людини. Відповідно, можливість доступу до освітніх практик людей похилого віку є базовою умовою у процесі активного старіння, а саме: як у підтримці фізичної форми так і їх активної участі у соціальному, економічному, культурному та громадянському житті.
\end{abstract}

Ключові слова: старіння населення, активне старіння, освіта протягом життя, самореалізачія громадян похилого віку, університет третього віку, мотивачія до навчання, соиіальне самопочуття.

\section{EDUCATION FOR ACTIVE AGING AS A CHALLENGE OF MODERNITY}

\section{Lutsk National Technical University}

The aging of the population today is becoming global. Under such conditions, the search for factors, that are decisive for constructive changes in this complex socio-demographic process, becomes important. Education is a factor in helping older people to stay socially and economically active, which means they are closely connected to the process of active aging.

The aim of the article is to analyze the characteristics of the educational activities of older people in the context of active aging.

The article considers the education of older people as an opportunity for individual, personal and professional development. It is determined that lifelong learning deepens understanding of the world around us and also provides more opportunities for improving the quality of human life. It is proved that the recognition and use of the skills and knowledge of older people as an important resource, as well as providing opportunities for constant participation in formal / non-formal education and professional development throughout life, is an important task of modern society. The problems that older people face in the educational process are analyzed. Accordingly, the possibility of access to educational practices of older people is a basic condition in the process of active aging, namely: both in supporting the physical form and their active participation in social, economic, cultural and civil life.

Key words: population aging, active aging, lifelong education, self-realization of elderly citizens, thirdyear university, motivation for learning, social well-being.

Постановка проблеми у загальному вигляді та ії зв'язок з важливими науковими і практичними завданнями. Одним із складних соціальних явищ, що набуває сьогодні глобального характеру є процес старіння населення. 3 цим пов'язаний ряд викликів, що виникають в економічній, політичній, демографічній, а також соціальній площині. Очевидно, що ці обставини детермінують зміну соціальних очікувань до людей похилого віку. Зокрема, можна виокремити такі тенденції у цьому процесі: подолання негативних стереотипів стосовно старості та старіння; використання професійного та індивідуально-особистісного досвіду людей похилого віку; залучення у соціальні, економічні, політичні практики сучасного суспільства; розвиток міжгенераційної солідарності, як базової умови розвитку суспільства. 
Пошуки чинників, що впливають на процес активного старіння сьогодні набувають особливо актуального значення. Зокрема, ряд питань, відповіді на які вимагають негайного вирішення: що є визначальним в активному старінні? За яких суспільних/індивідуальних умов активне старіння може відбуватись? За яких обставин люди похилого віку можуть бути як соціально включеними, так i, навпаки, ізольованим? Чи є освіта тим чинником, що сприяє у допомозі людям похилого віку залишатися соціально та економічно активними?

Аналіз останніх досліджень, у яких започатковано вирішення проблеми. Проблема освіти людей похилого віку у науковій площині - сьогодні $є$ одним із пріоритетних іiі напрямків. Зокрема, значний внесок у дослідження можливостей розвитку інтелектуальних та когнітивних здібностей людей похилого віку зробили такі вчені, як Агапова О., Альперович В., Анциферова А., Балл Г., Батлер Р., Еріксон Е., Лідері А., Левінсон А., Громкова М., Дейв. Р., Дзюба Т., Дрейвс В., Кононигіна Т., Кравець Н., Кулюткін Ю., Ліберман Я., Ноулз М., Роджерс К. Становських 3., Тимчук Л., Торндайк Е., Фельдштейн Д., Шльосек Ф.. Проблема обгрунтування специфіки освітніх технологій для людей похилого віку представлено у працях Андреєва В., Андрущенко В., Батишева М, Бевза Г., Бикова В., Богіва Е., Вершловського С., Гаврикова А., Десятова Т., Зеєра Е., Кагана М., Ковальчук В., Липкіної І., Лугового В., Огієнка О., Прийми С..

Цілі статті - аналіз особливостей освітньої діяльності людей похилого віку у контексті активного старіння.

Виклад основного матеріалу дослідження 3 повним обгрунтуванням отриманих наукових результатів. Наприкінці 1990-х років Всесвітня організація охорони здоров'я (BOO3) ввела концепцію активного старіння в площину політики та економіки, а саме: активне старіння - процес оптимізації здоров’я, участі та можливостей безпеки 3 метою поліпшення якості життя людини у похилому віці [1]. Можна стверджувати, що розвиток цієї концепції сприяв новому підходу до розуміння старості та процесу старіння, а також формуванню позитивного образу людини літнього віку. В першу чергу, мається на увазі підтримка фізичної форми та можливість якнайдовше виконувати роботу для літніх людей, а також їх активну участь у соціальному, економічному, культурному та громадянському житті.

Згідно даних міністерства соціальної політики України "Україна входить до 30 найстаріших країн світу за часткою осіб віком 60 років і старше: у 2015 році вона становила $21,8 \%$, а частка людей віком 65 років і старше - 15,5 \% від загальної чисельності населення. Згідно з національним демографічним прогнозом до 2025 року частка осіб віком понад 60 років становитиме 25,0\% загальної кількості населення, віком 65 років і старше - 18,4 \%, у 2030 році - понад $26 \%$ і понад $20 \%$, відповідно. Довготривалою особливістю старіння населення в Україні $\epsilon$ його переважна обумовленість зниженням народжуваності та високим рівнем передчасної смертності без відчутного збільшення тривалості життя" [2].

Відповідно, що у таких обставинах, де з однієї сторони у площині сучасного суспільства відбувається стрімкій ріст технологічних та соціальних змін, а з іншої глобальне старіння населення, питання освіти людей похилого віку набуває особливо актуального значення. За таких умов, важливим завданням суспільства $є$ формування державної стратегії в основі якої - визнання та використання навиків та знань людей похилого віку як важливого ресурсу, а також забезпечення можливостей для постійної участі у формальній/неформальній освіті та професійному розвитку протягом усього життя. Адже, для того, щоб люди похилого віку могли, наприклад, вивчати іноземні мови, опановувати нові технології суспільство повинно комплексно підходити до вирішення цієї проблеми.

Також, варто відзначити, що проблеми, з якими зіштовхуються люди похилого віку здебільшого мають соціально-економічний характер. Втрата конкурентоздатності на ринку праці, зміна соціального статусу, погіршення матеріального становища, 
зниження соціальних контактів - це ті події, які впливають на якість життя людей похилого віку. Власне, такі фактори призводять до неможливості самореалізації цієї вікової групи, стають причиною соціальної ізоляції та вікових кризисів. Одним із можливих шляхів вирішення цих проблем у другій половині XX та на початку XXI століття стає освіта для людей похилого віку.

Важливо відмітити, що пошуки шляхів вирішення проблеми освіти людей похилого віку сьогодні відбуваються у багатьох країнах. Так, у 2002 році у Мадриді був прийнятий Мадридський міжнародний план дій по проблемам старіння [3], згідно якого надання людям похилого віку доступу до освіти є однією із важливих умов їх інтеграції в життя суспільства. Україна також долучилася до вирішення цієї проблеми. Зокрема, Урядом схвалено план заходів 3 реалізації Стратегії державної політики 3 питань здорового та активного довголіття населення на період до 2022 року, де важливими завданнями є: поліпшення умов для самореалізації громадян похилого віку та їх участі у процесах розвитку суспільства; сприяння ініціативам з обміну досвідом і знаннями між поколіннями, розширення можливостей для передачі накопиченого досвіду працівниками похилого віку; формування політики навчання протягом життя 3 метою залучення громадян похилого віку до участі в освітніх процесах, розширення можливостей оволодіння новими професійними та загальноосвітніми навичками, зокрема у сферах сучасних комунікацій, комп'ютерної та інформаційної грамотності[2].

У науковому дискурсі сьогодні спостерігається значна кількість досліджень проблеми освіти для активного старіння, де важливим висновком $є$ те, що: "Навчання протягом усього життя може сприяти активному старінню, а також, що безперервне навчання дає людям похилого віку багаточисельні переваги для когнітивного функціонування, здоров'я і благополуччя, участі в житті суспільства та впевненості в coбi” [5].

Теоретичне осмислення значення ролі освіти для людей похилого віку бере свій початок 3 середини 70-х років XX століття. Перший університет для цієї вікової категорії людей був заснований у 1973 році у Тулузі П.Веллом. Сьогодні існує уже значна кількість закладів та різноманітних організацій, серед яких - університети, курси, товариства, майстер -класи, навчальні центри для людей похилого віку. Аналіз діяльності цих закладів дозволяе виокремити наступні напрямки освітніх практик людей похилого віку:

- навчання комп'ютерної та цифрової грамотності;

- фінансова грамотність;

- творча та прикладна діяльність;

- дизайн, садівництво;

- вивчення іноземних мов;

- волонтерська діяльність.

У реалізації концепції активного старіння освіта виконує щонайменше чотири функції: адаптивну, інтегруючу, комунікативну, компенсуючу.

Адаптивна функція полягає в отриманні знань та навиків, які є необхідними у сучасних повсякденних практиках, допомогти людям похилого віку пристосуватися до змін, що відбуваються в соціальній, економічній та політичній площині; інтегруюча функція у сучасних умовах проявляється у подоланні соціального та культурного ейджизму; комунікативна відповідає за задоволення однієї із базових потреб людини протягом усього ії життя - у спілкуванні та безпосередніх контактах з іншими людьми; компенсуюча функція полягає у тому, що освіта сприяє поповненню тих знань, які раніше були відсутніми або ж є недостатніми у силу швидких темпів зростання сучасних технологій. наступні:

Серед основних завдань освіти людей похилого віку важливо виокремити

$\begin{array}{ll}\checkmark & \text { оновлення та доповнення знань та вмінь; } \\ \checkmark & \text { встановлення нових та підтримка існуючих соціальних зв'язків; }\end{array}$ 
$\checkmark \quad$ формування позитивної самооцінки;

$\checkmark$ подолання негативного стереотипного образу людини похилого віку (залежної, немічної, соціально ізольованої);

$\checkmark \quad$ адаптуватись до сучасних обставин життя;

$\checkmark$ формування позитивного емоційного стану;

$\checkmark \quad$ покращення якості життя людей похилого віку.

Аналізуючи становище літніх людей з точки зору можливостей, які пропонує освіта потрібно враховувати і бар'єри, що утруднюють можливість бути активним учасником навчальної діяльності. Переважно це - проблеми зі здоров'ям, послаблення зорового та слухового сприйняття, а також обмежена рухова активність. Освіта людей похилого віку не принесе таких результатів, які очікують стосовно молоді. Доступ до освіти може бути послаблений відсутністю мотивації до навчання, фінансовими труднощами, психічними бар'єрами. Усунення таких перепон буде сприяти розвитку освіти серед людей старшого віку.

Також, важливим $є$ розуміння особливостей самої організації навчального процесу для людей похилого віку. Процес навчання повинен бути побудований системно, з розумінням специфіки засвоєння нової інформації людьми похилого віку. Необхідними тут є міждисциплінарні знання з психології, геронтології, та, зокрема, медицини. Адже, очевидним є те, що навчати людей похилого віку, так як і молодь неможливо. Базовими основами такого навчання є: забезпечення довірливої атмосфери та взаємної поваги; розуміння фізичних можливостей людей цієї вікової категорії (наприклад, використання наочних матеріалів, які підготовлені 3 врахуванням особливостей зору, швидкості реакції, дрібної моторики, а також, обов'язково - зручне робоче місце); скорочена тривалість занять та часті перерви.

Також потрібно додати, що в сучасних умовах українське суспільство тільки починає усвідомлювати необхідність створення умов для навчання людей будь якого віку. Саме тому сьогодні $є$ недостатньо розвинені освітні структури, що можуть надавати людям похилого віку освітні послуги відповідно тим вимогам, які $\epsilon$ адекватними сучасним обставинам.

У процесі інституціоналізації освіти людей похилого віку вагомого значення набуває така форма навчання як Lifelong Learning, навчання протягом життя. Її мета можливість розвивати та реалізовувати різноманітні навчальні інтереси людей незалежно від їх віку. Варто відзначити, що однаковий доступ до можливостей навчання $\epsilon$ неодмінною умовою реалізації права на освіту для всіх. Характерною рисою політики навчання протягом усього життя $\epsilon$ - формування позитивного ставлення до навчання як в індивідуально-особистісному напрямку, так і в професійному.

Можна стверджувати, що саме концепція навчання протягом життя та іï̈ активна реалізація в освітній площині сприяла розвитку освіти для людей похилого віку. Адже, людина, яка навчається не лише у школі чи університеті, а займається освітньою діяльністю постійно - це людина мотивована розвиватись. Навчання протягом життя поглиблює розуміння навколишнього світу, а також надає більше можливостей для покращення якості життя людини.

Можна зробити висновок, що освіта людей похилого віку є важливим чинником у процесі активного старіння. Освітня діяльність у процесі активного старіння впливає, перш за все, на формування культури старіння в суспільстві загалом, а також сприяє позитивному прийняттю себе у “срібному віці". 3 іншої сторони, є визначальним чинником у формуванні позитивного ставлення до людей похилого віку, як активних учасників у житті суспільства, та як таких, що корисними завдяки індивідуальноособистісному та професійному досвіду.

\section{Список бібліографічного опису}

1. Active ageing. A policy framework. World Health Organization, Madrid 2002. URL: http://whqlibdoc.who.int/hq (дата звернення: 09.03.2020).

2. Уряд схвалив Стратегію державної політики з питань здорового та активного довголіття населення на період до 2022 
poкy. https://zakon.rada.gov.ua/laws/show/688-2018-\%D1\%80 (дата звернення: 15.03.2020).

3. Madrid Plan of Action and its Implementation. URL: https://www.un.org/development/desa/ageing/madrid-plan-of-action-andits-implementation.html (дата звернення: 15.03.2020).

4. Sandra von Doetinchem. Lifelong Learning: The Essential Element of an Engaged and Active Lifestyle. URL: https:/www.asaging.org/blog/lifelong-learning-essential-element-engaged-and-active-lifestyle(дата звернення: 20.03.2020.)

\title{
References
}

1.Active ageing. A policy framework. World Health Organization. URL: http://whqlibdoc.who.int/hq (last access: 09.03.2020). 2.The Government has approved a public policy strategy for healthy and active life expectancy for the period up to 2022 . https://www.msp.gov.ua/news/14645.htm (last access: 15.03.2020).

3.Madrid Plan of Action and its Implementation. URL: https://www.un.org/development/desa/ageing/madrid-plan-of-action-and-itsimplementation.html (last access: 15.03.2020).

4.Sandra von Doetinchem. Lifelong Learning: The Essential Element of an Engaged and Active Lifestyle. URL: https://www.asaging.org/blog/lifelong-learning-essential-element-engaged-and-active-lifestyle (last access: 20.03.2020).

Дата подання публікації 20.03.2020 р.

УДК 336:004.896(07)

Пиріг С. О., к.е.н., доцент

Pyrih S. Candidate of Economic Sciences, Associate Professor https://orcid.org/0000-0002-1205-9814

\section{ВИКОРИСТАННЯ ТАБЛИЧНОГО РЕДАКТОРА МS ЕХСЕL У МЕТОДИЧНІЙ РОБОТІ НАУКОВО-ПЕДАГОГІЧНИХ ПРАЦІВНИКІВ ВИЩОГО НАВЧАЛЬНОГО ЗАКЛАДУ}

\author{
Луцький національний технічний університет
}

У статті розроблено автоматизований шаблон навчального плану для здобувачів вищої освіти за освітнім ступенем «бакалавр» за допомогою табличного редактора MS Excel.

Розглянуто один із методів автоматизації методичної роботи на прикладі складання навчального плану засобами офісного пакету, зокрема програми табличного редактора MS Excel, як зручного та зрозумілого у використанні користувачами, які не є фахівцями у галузі інформаційних технологій.

Запропоновано та обгрунтовано доцільність використання табличного процесора та його вбудованих функцій зокрема таких функцій, як: СУММ(), СЧЁТЕСЛИ(),СУММЕСЛИ(), ЕСЛИ(), ИЛИ(),СЧЁТЗ(), які допоможуть швидко та просто досягти поставленої мети.

Ключові слова: табличний редактор MS Excel, навчальний план, інформаційні технології, інформаційна компетентність, науково-педагогічні працівники.

\section{USING THE MS EXCEL TABLE EDITOR IN THE METHODICAL WORK OF SCIENTIFIC AND PEDAGOGICAL WORKERS HIGHER EDUCATIONAL INSTITUTION}

\section{Lutsk National Technical University}

The article develops an automated curriculum template for higher education undergraduate students using the MS Excel spreadsheet editor.

One of the methods of automation of methodical work on the example of curriculum development by means of office package, in particular the program of table editor MS Excel, as convenient and clear in use by users who are not experts in the field of information technologies is considered.

The expediency of using a spreadsheet processor and its built-in functions, in particular, such functions as: $\operatorname{SUM}(), \operatorname{COUNTIF}(), \operatorname{SUMIF}(), \operatorname{IF}(), \mathrm{OR}(), \operatorname{COUNTA}()$, which will help to quickly and easily achieve the goal, is proposed and substantiated.

Key words: MS Excel spreadsheet editor, curriculum, information technology, information competence, research and teaching staff.

Постановка проблеми у загальному вигляді i iï зв'язок 3 важливими науковими та практичними завданнями. Знайти сферу, в якій не використовуються інформаційні технології сьогодні неможливо. Не виключенням є також і заклади вищої 
освіти, де науково-педагогічні працівники у своїй методичній роботі використовують прикладні програмні засоби загального призначення і звичайно табличний редактор 